\title{
Anthrovision
}

ANTHROVISION

Vaneasa Online Journal

$3.1 \mid 2015$

Varia 3.1

\section{The Lace Curtains of Berlin}

\section{Izai Amorim}

\section{(2) OpenEdition}

\section{Journals}

Electronic version

URL: http://journals.openedition.org/anthrovision/1470

DOI: 10.4000/anthrovision. 1470

ISSN: 2198-6754

\section{Publisher}

VANEASA - Visual Anthropology Network of European Association of Social Anthropologists

\section{Electronic reference}

Izai Amorim, «The Lace Curtains of Berlin », Anthrovision [Online], 3.1 | 2015, Online since 18 October 2015, connection on 19 April 2019. URL : http://journals.openedition.org/anthrovision/1470 ; DOI : 10.4000/anthrovision. 1470

This text was automatically generated on 19 April 2019.

(c) Anthrovision 


\title{
The Lace Curtains of Berlin
}

\author{
Izai Amorim
}

\section{Lace Curtains as Communcation Tools}

1 Someone hangs a curtain for at least three possible reasons: to control the amount of light that gets inside the room; to block the view and so to ensure privacy; and to decorate the room. One could say that in the first two cases curtains function as technical tools, in the third case as ornaments.

2 While judging the third case - ornament - is a subjective matter, the effectiveness of the curtains as technical tools can be gauged objectively: how far can you block the light and the view - totally, partially or not at all?

3 The lace curtains studied in the project "The Lace Curtains of Berlin" tend to only partially accomplish their two functions as technical tools. The fabric, almost transparent, doesn't block much light. Most styles don't cover the window surface completely and therefore allow outsiders to look in, not really guaranteeing much privacy.

4 We must therefore assume that the main - or maybe even sole - function of the lace curtains is decoration. Maybe the possibility of dimming the light or gaining privacy is simply irrelevant to the people who have these curtains. Or maybe these people think that these lace curtains fulfill their function as ornaments and embellish their rooms so well that everything else becomes secondary. 
The Lace Curtains of Berlin - Ratibor Street Collection

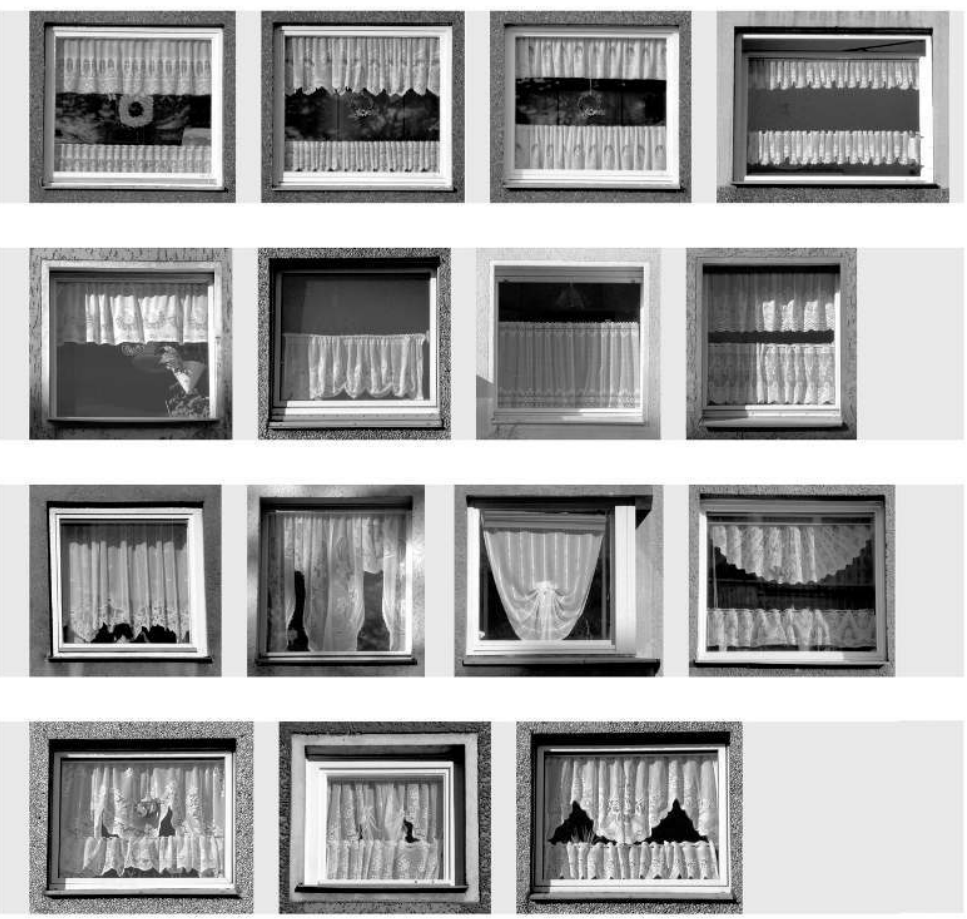

Photography and montage by Izai Amorim

Ornaments can be - and most of the time are - communication tools. We can express our identities, make statements, and send non-verbal messages to the world via the ornaments we choose to use - whether consciously or unconsciously. The project 'The Lace Curtains of Berlin' is based on my assumption that the lace curtains are very efficient communication tools. 

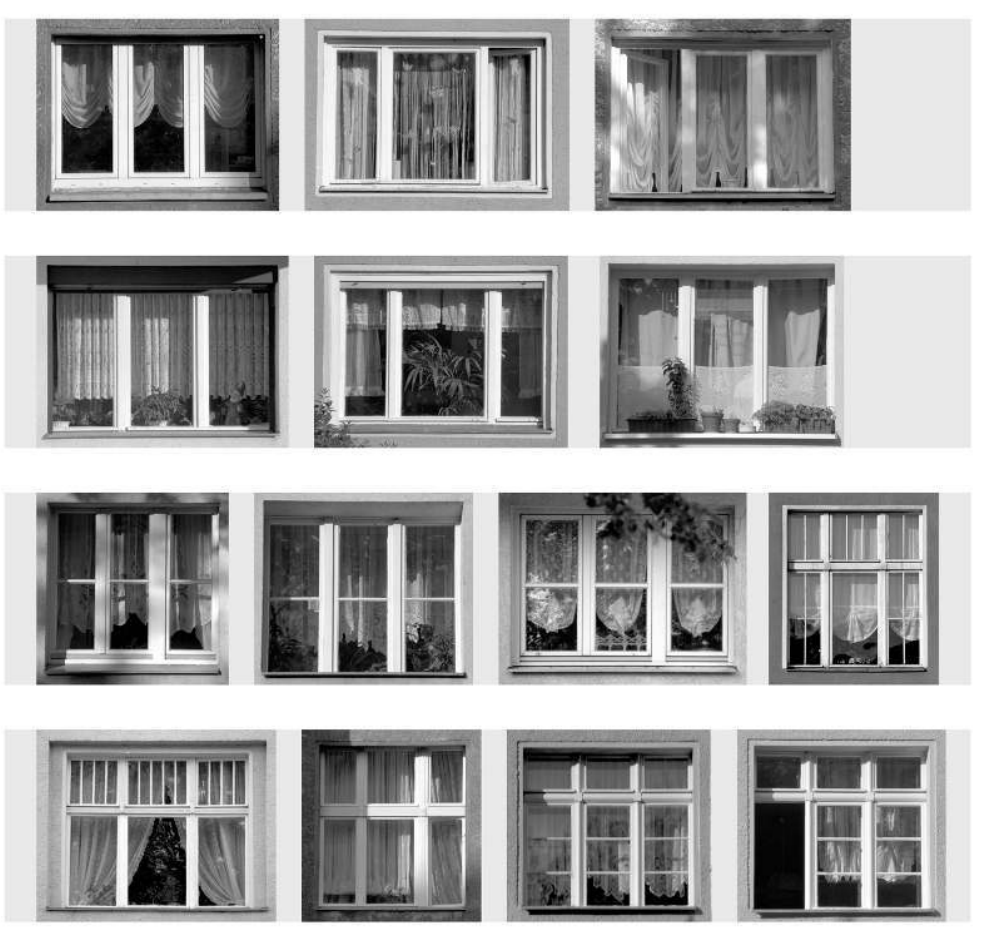

Photography and montage by Izai Amorim

\section{The Sender's Message}

6 Before we continue we must first define some terms we need in order to explain this assumption. Please note that there are different definitions for the following terms, but let's agree that, in a very simplified definition, Communication is about a Sender transmitting a Message to a Receiver by emitting Signals through a Channel. A Code is used by the Sender to structure the Message and by the Receiver to decipher it. For example, let's consider a message in Morse code: the Sender transmits sounds (Signals) via a wire (Channel); the Receiver deciphers the Message using Morse code (Code). For another example, let's take a book: the writer (Sender) has words (Signals) printed on paper (Channel); the reader (Receiver) knows the language (Code) and understands the text.

Then there is Context, which can be defined as an extension of - or complement to - the Code. Single words can have different meanings. For example, the word "tire" can be both a verb (to lose energy) and a noun (a rubber covering for a wheel). The Context in which the word is used determines its meaning. Not only words but whole phrases are embedded in Context. The phrase "Oh God, please, stop it," means different things if spoken by someone while praying in church or by someone talking to a friend in a bar.

This applies also to messages of the non-verbal kind. Wearing black in a funeral in a western country almost certainly means "I'm mourning," while in a cocktail party it could be interpreted as "I'm an intellectual," or "I like wearing black," since we don't expect mourning people to go to cocktail parties. 

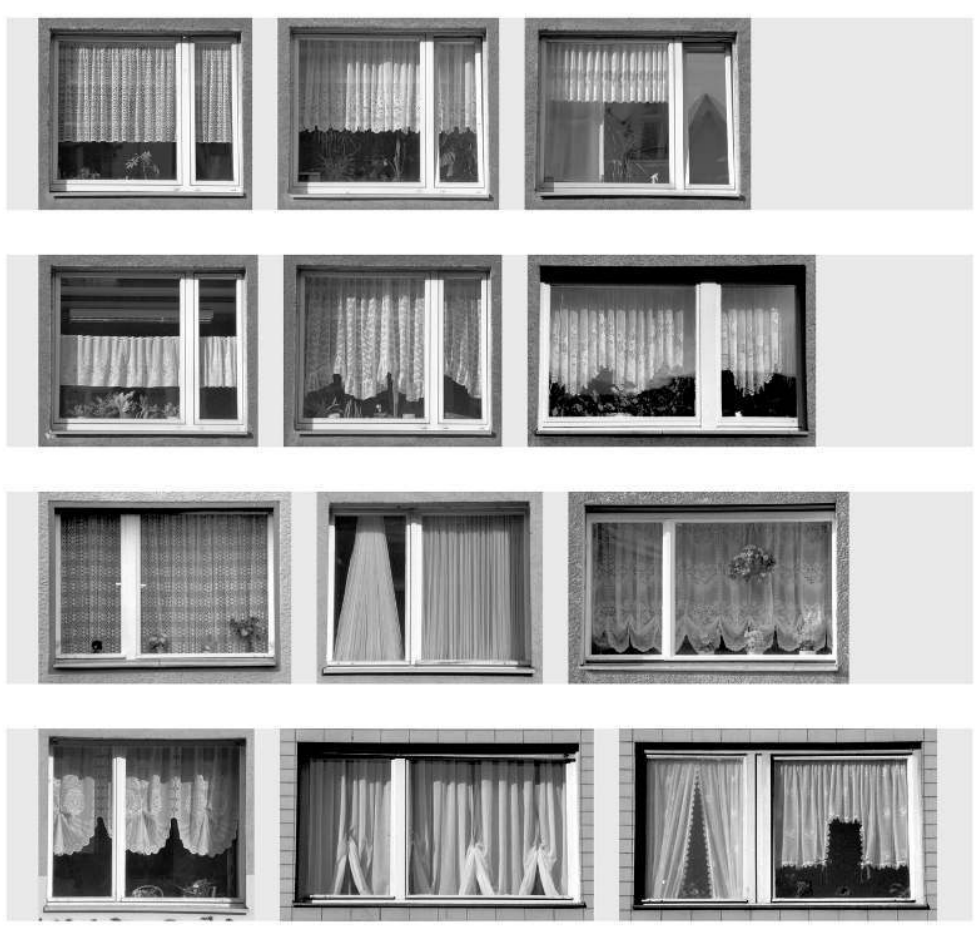

Photography and montage by Izai Amorim

Since lace curtains are communication tools of the non-verbal kind, we should address a few extra issues. Depending on the circumstances, a non-verbal communication tool can be a Channel, a Signal, or even a Message in itself. For example, light: it is a Channel if used to project a movie on a screen; it is a Signal if used to transmit a message in Morse code, like the navy used to do decades ago, from ship to ship; it is a Message when someone afraid of burglars leaves some lights on inside his house when going out after dark, saying, "There is someone home, you'd better break in somewhere else."

\section{The Receiver's Perception}

This applies to ornaments, too. Let's consider a piece of jewelry, say a wedding ring: it can be a Channel if there are words or signs engraved in it, like the date of the wedding and the name of the partner; it can be a Signal, transmitting the Message "I'm married," to those who know the Code; it can be a Message, "I'm rich and can afford such an expensive ring." Most of the times it is Channel, Signal, and Message simultaneously. This seems very clear when seen from the Sender's point of view. But the crucial link in any chain of communication is the Receiver, who will decipher the Message according to the Code known to him/her and in his/her own cultural Context. This can lead to the message being partially or completely lost. Staying with the wedding ring of the example above, if the Receiver belongs to a culture where wedding rings are not used (missing Code), he/ she might not get the Message "I'm married" at all; if in his/her culture one wears the wedding ring on the left hand (different Code), a ring on the right hand might be understood as a Signal for "engaged but not yet married;" if the Receiver has a different 
aesthetic sensibility, the Message might be understood as "You might be rich but you have a very bad taste for rings."

Let's move on to clothes, which, like the lace curtains, are both textile ornaments and communication tools. A sweatshirt can obviously be a Channel if you print a phrase on it like "Save the planet!" It can be a Signal if it has a school logo on it, transmitting the Message "I attend, or attended, this school." But it can also be a Message in itself: "The person wearing this sweatshirt is a..." The blanks are filled in according to the logo you put on the sweatshirt combined with the demographics of the brand users. It can mean "cool," "uncool," "trendy," "old-fashioned," "conservative," "upper class," "work class," etc. But the Message is only understood in the way wished by the Sender wearing the branded sweatshirt if he/she belongs to the consumer group usually associated with it. It is therefore possible to wear a sweatshirt supposed to be "cool" and still look "uncool" if you don't have the gender, age, or income class associated with the brand.

The Lace Curtains of Berlin - Glogauer Street Collection

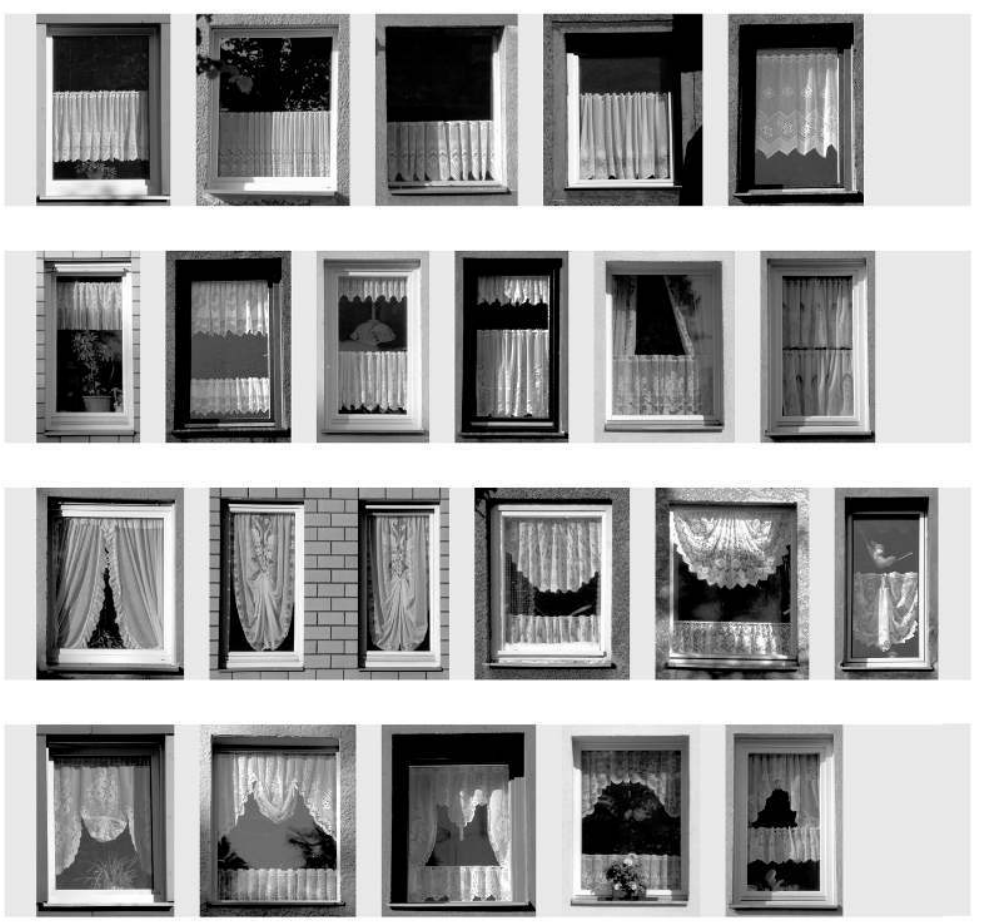

Photography and montage by Izai Amorim

\section{Rainer-Werner's Perception}

Now we can finally start analyzing the ornaments that interest us, the lace curtains of Berlin. Let's try to figure out which kind of communication tool they can be, using the terms we have defined above. Imagine one person walking around Berlin, noticing the lace curtains for the first time, and taking interest in them. For the sake of convenience let's call this person Rainer-Werner. Rainer-Werner will eventually form an opinion about their aesthetic appeal - or lack thereof. But will he also see that they are communication 
tools? And if yes, will he see the curtains as Signals or Messages? (Since none of these curtains have phrases or other signs printed on them, Channels would not be a choice.)

If Rainer-Werner spends a lot of time walking around Berlin and checking which windows have lace curtains and which don't, after a while he will notice certain correlations between the curtains and their environment. He will know which Berlin neighborhoods have the biggest concentration of lace curtains; inside a given neighborhood, which kind of buildings have more curtains than others; which kind of cars are usually parked in front of these buildings; which kind of furniture can be seen from the street in the apartments with lace curtains; etc.

Sooner or later, based on the observed correlations, Rainer-Werner will be able to make educated guesses about the sociological, educational, and professional backgrounds of people living in a given apartment based on the presence or absence of lace curtains in the windows. He will be able to say "The person living behind this curtain is a..." At this stage, this will be only his subjective opinion. The important thing is, he will then see the lace curtains as Messages. To fill in the blanks more precisely, Rainer-Werner can use the tools available to social scientists and market researchers and follow up his empiric observations with a study and so test his assumptions. Some will be confirmed, others won't. There will be some surprises. But in the end he will have very sound results.

\section{The Lace Curtains of Berlin - Görlitzer Street Collection}
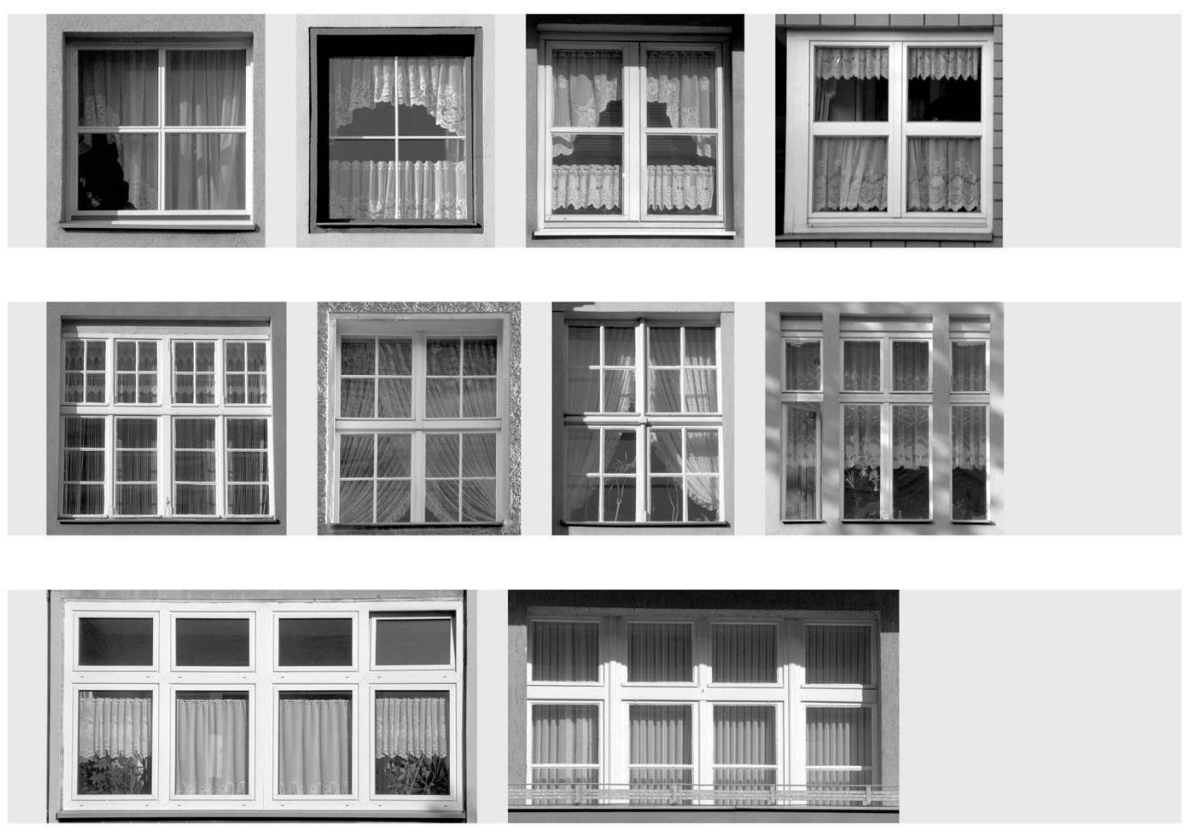

Photography and montage by Izai Amorim

Basically he will have to interview the Senders, enough of them to make the study statistically relevant. He will ask them questions about their lives, tastes, preferences, etc. Most important, he will ask each one of them, "Which message are you sending with this particular curtain?" At the end he will have a pretty good profile of these people. 


\section{Rainer-Werner's Analysis}

Depending on how generous his research grant or marketing budget was, Rainer-Werner will be able even to profile the Senders according to curtain type. He can then either publish his academic paper "Berliners and their Lace Curtains: A Sociological Profile," or his marketing study "Berlin's Stealthy Demographic Groups: How to Sell to Lace Curtain Lovers."

Both would make interesting readings. In "Berliners and their Lace Curtains: A Sociological Profile," one could learn that people with profile P1 tend to like lace curtains of the kind LC7, while profile P2 tends to like LC2 and LC5. Profile P3 tends to combine LC1 and LC3, while Profile P4 will never have LC8. And so on and so forth. Having the profile definitions, one could look at a lace curtain and know exactly which kind of person lives in the apartment.

The Lace Curtains of Berlin - Forster Street Collection
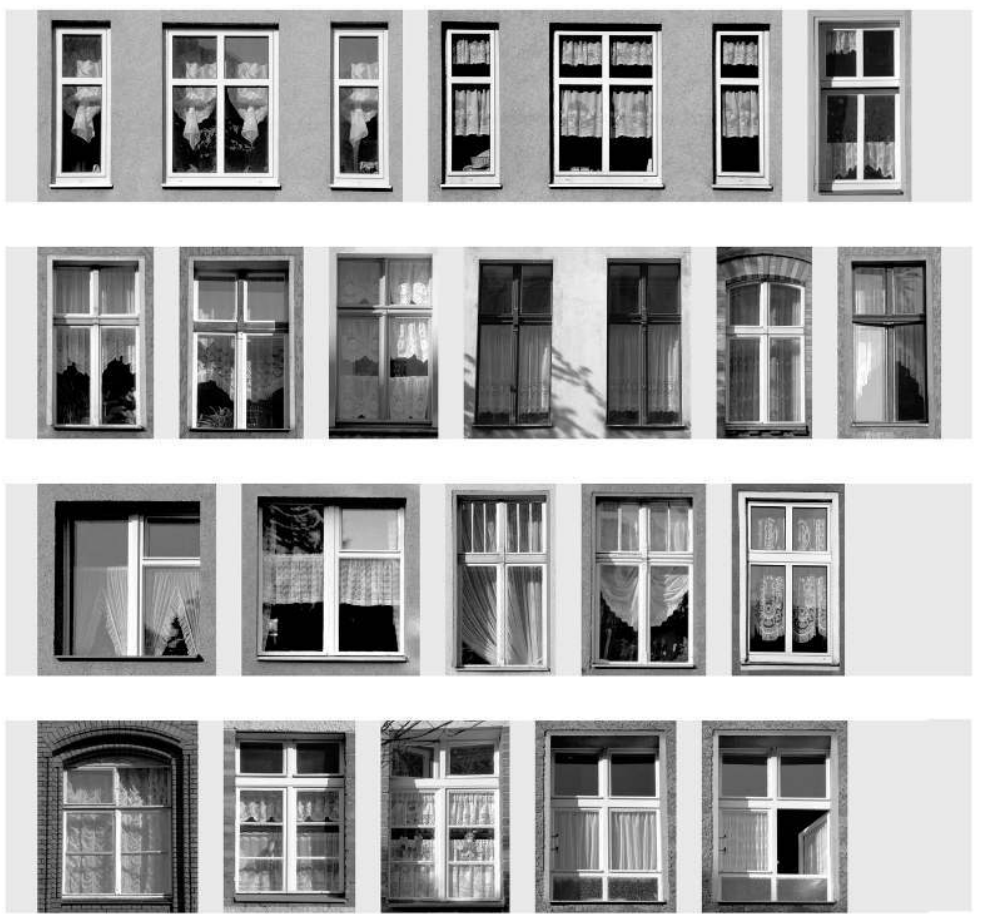

Photography and montage by Izai Amorim

“Berlin's Stealthy Demographic Groups: How to Sell to Lace Curtain Lovers," one learns that profile P1 tends to keep a pet ("Sell pet food to them!") while profile P2 watches a lot of television ("Sell them subscriptions to TV magazines!"). If you are a salesperson knocking on doors, look out for curtain type LC23: the people hanging them open the door $60 \%$ of the time while the average is only $20 \%$. But avoid curtain type LC8: they will talk to you for a long time (loneliness) but will buy only $5 \%$ of the time. And so on and so forth. Having the profile definitions, one would be able to fine-tune sales calls.

As we can see, classifying the lace curtains as Messages and not as Signals seems to be the right choice to make - especially to socials scientists and market researchers. You can use 
proven scientific methodology to gather and analyze your data; you can obtain satisfying results; you can publish interesting literature based on your research.

But for the sake of completeness let's explore the other possibility: lace curtains as Signals. Let's assume that Rainer-Werner chooses Signals instead of Message. Which results could we expect, if any? Why should he do it? Well, let's assume that RainerWerner, like Hamlet, believes that "there are more things in heaven and earth than are dreamt of in our philosophy." He is not interested in individual curtains but in their combination. He wants to know what it means when one sees LC1 in a given window combined with LC5 one floor above and LC8 one floor below.

\section{LC1 combined with LC5 above and LC8 below}

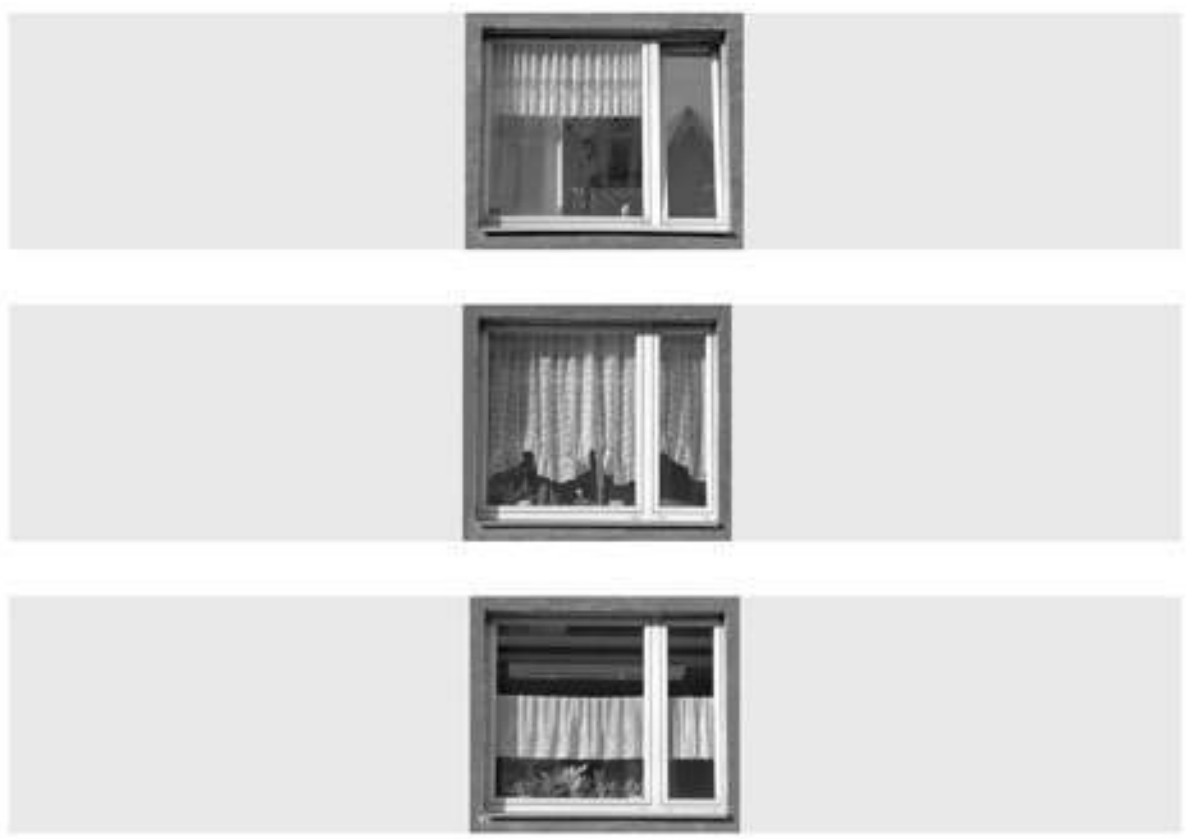

Photography and montage by Izai Amorim

This choice of curtains as Signals is highly problematic. First, there is no identifiable Sender. While individual curtains could be possibly seen as Signals transmitted by specific Senders (the people living in the apartments), for the combination of multiple curtains in one or various buildings this is impossible. No one coordinates which curtains should be displayed in which combination in a given building or neighborhood. The combination that results from many individuals hanging their own curtains is completely random. This excludes the existence of a Code, too. And if there are no Senders and no Code, the curtains can't possibly be Signals, right?

Not to Rainer-Werner. He firmly believes that there is a Code and intends to crack it. One could describe his intentions as "the discovery - or invention - of a Code to decipher Messages based on the random combination of Signals without a Sender". Kind of a silly proposition, one could argue. 


\section{The Receivers' Codes}

What if Rainer-Werner thinks that, like beauty, meaning is in the eye of the beholder? $\mathrm{He}$ would then say, "Isn't astronomy also about the invention of a Code to decipher Messages based on the random combination of Signals without a Sender? Who needs a Sender? The Receiver is the key point! If the Receiver is given a Code, he will understand the Signals, even if the Signals were originated randomly. If it worked for astrology, why wouldn't it for lace curtains?"

ainer-Werner has a great interest in astronomy. To scientists willing to listen without rolling their eyes, he will explain that his fascination is due to the psychological, anthropological, and even theological facets of the belief in astronomy - as well as the historical aspects of its development.

\section{The Lace Curtains of Berlin - Reichenberger Street Collection}

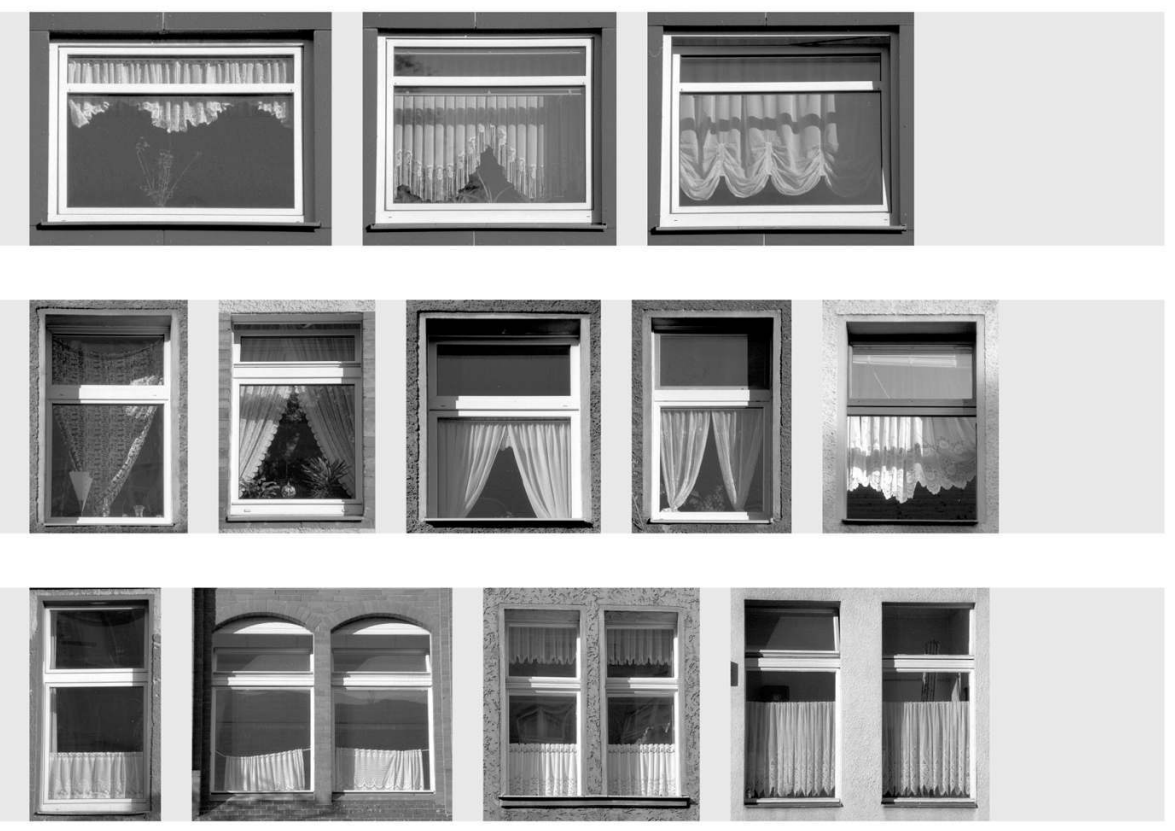

Photography and montage by Izai Amorim

25

Many thousands years ago some people started to study the position of the planets in the night sky and to make correlations to the behavior of people on Earth. They then developed the twelve signs of the zodiac and assigned personality traits to people born under these signs. The rest, as they say, is history. Scientists might argue that astronomy is basically correlation without causation. One can find correlations between totally unrelated events. Proving the causation is hard work - and sometimes impossible to do. On top of that, astronomy requires big a dose of self-delusion. But does it all matter to the millions of people who believe that certain events are to be expected when the planets are in a given position? Correlations are more than enough, Rainer-Werner would argue. The ability to self-delude ourselves is one of traits that make us human and it's available in very big doses. 

looking at them the Receivers. How do they react to a certain combination of curtains? Which kind of meaning do they assign to them? Which feelings, thoughts, events, do they believe that a certain combination of curtains will trigger?

Une astrology, it won't take thousands of years to crack the Code. Rainer-Werner can use the same methodology used by the social scientists and market researchers to interview the people on the streets, the Receivers. He also has access to databases covering almost all fields of knowledge. He can feed all this data into very powerful computers and let them crunch the numbers. Sooner or later he will find the correlations he is looking for and he will be able to manufacture the Code.

He can then create a (picture) dictionary, a grammar, and a textbook of lace-curtain communications. The dictionary would tell us how many different curtains are there (Signals). The grammar would explain how the words are normally put together (sequence of Signals). The textbook would explain the meaning of it all (Code).

29 So that, standing in front of a building, one could decipher the meaning of the combination LC2, LC4, LC27 on the third floor, LC15, LC3, LC5 on the second floor, and LC9, LC17, LC12 on the first floor.

\section{Analysis of Combinations of Lace Curtains}

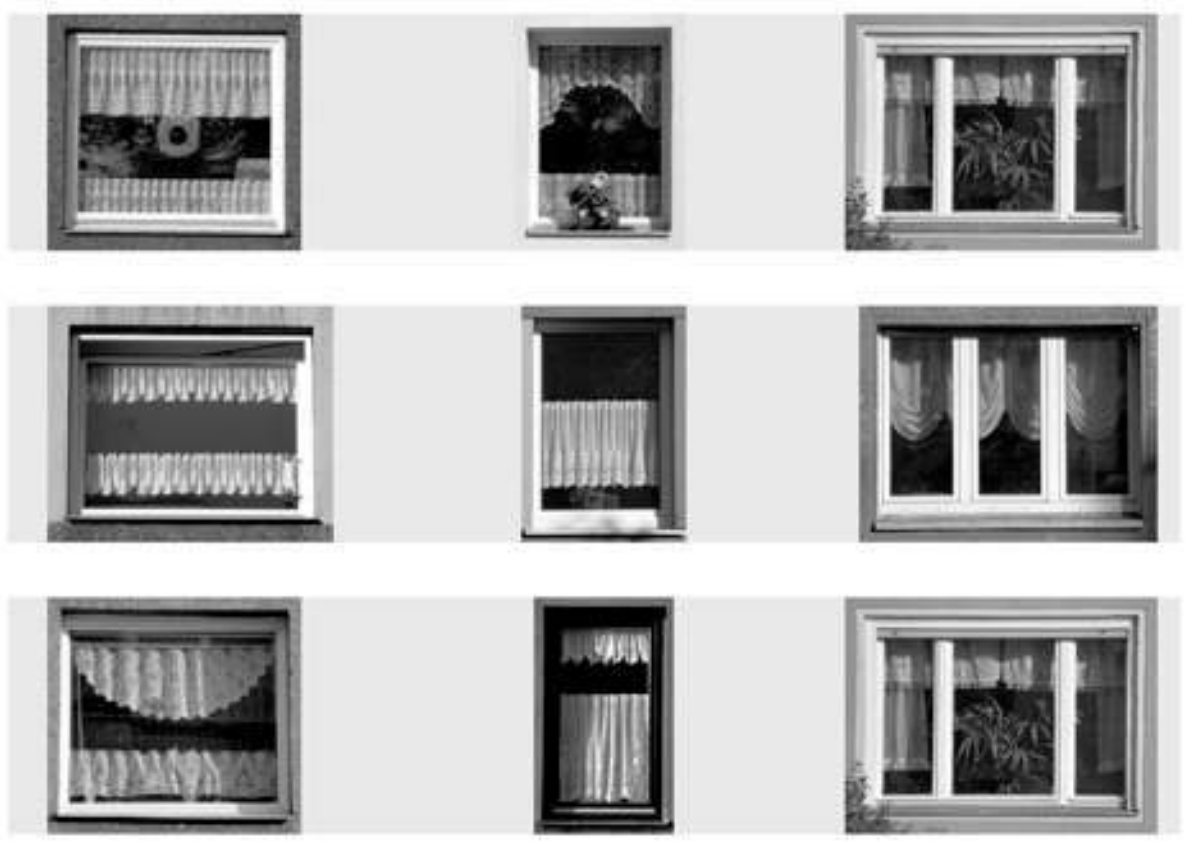

Combination LC2, LC4, LC27 (third floor), LC15, LC3, LC5 (second floor), and LC9, LC17, LC12 (first floor)

Photography and montage by Izai Amorim

People move in and out of apartments, taking their curtains with them. The curtain landscape changes with time in a given building and street. What do the changes mean to the person observing them? What will the replacement of LC22 by LC35 mean? 

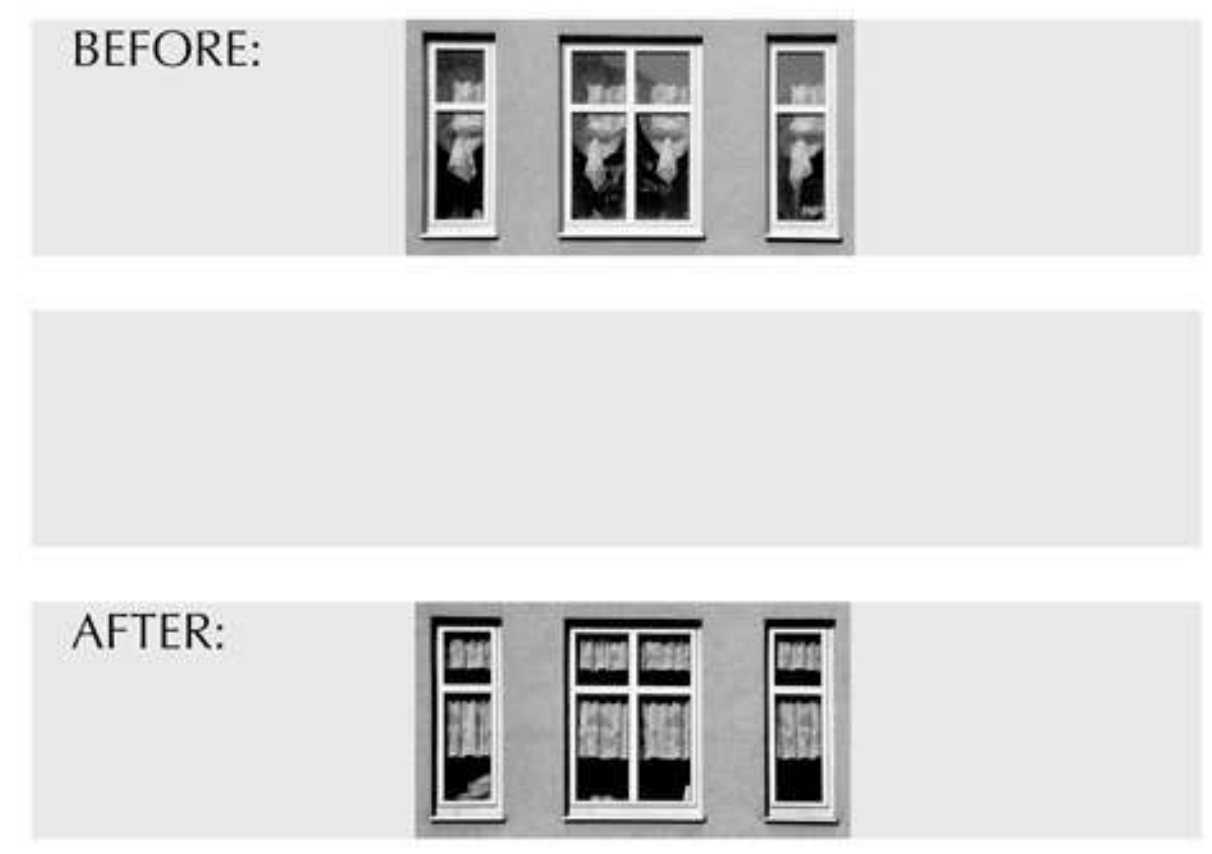

LC22 (above) was replaced by LC35 (below)

Photography and montage by Izai Amorim

\section{Lace Curtainology}

One could argue that dictionary, grammar, and textbook are not science but art, but the distinction isn't relevant to Rainer-Werner. And as long as he keeps all this work of art to himself, this won't matter much to the world. The interesting thing would be if he started to spread this knowledge, share his art. What if people paid attention to him, liked the idea, and started to see meaning in randomly combined curtains? Could Rainer-Werner's artwork acquire a life of its own? Like astrology, could it also become a science - or a pseudo-science, according to where you stand on these matters? For a lack of a better word let's call it "Lace Curtainology."

Far fetched? Maybe. But how many cultural phenomena are intentionally manufactured and let loose to spread around and grow? From new religions to fashion trends, this process has been going on for millennia. So there is definitely room for lace curtains as Signals if one is able and willing to manufacture the code and to spread it - and to convince many people to accept and use it.

Before any study is possible, however, whether on lace curtains as Message or Signals, one needs to take stock: How many kinds of curtains are there? In which neighborhoods are they located? Etc.

The photographic essay "The Lace Curtains of Berlin" is a first step in this direction. It shows about 200 lace curtains, which is only a fraction of what is available. The curtains are grouped - for aesthetic purposes only - in eight different "families" or "collections" according to window type: form, number of divisions, etc. 

invited to enjoy the lace curtains' textile poetry and to decipher their messages. I also hopes to inspire someone to study these Messages seriously - hopefully a social scientist since the last thing in the world we need is more advertising. someone does go down the Signal road and starts to crack the Code, I would be very amused but not surprised! This road does offer a lot of potential for some very creative artistic work.

Any takers?

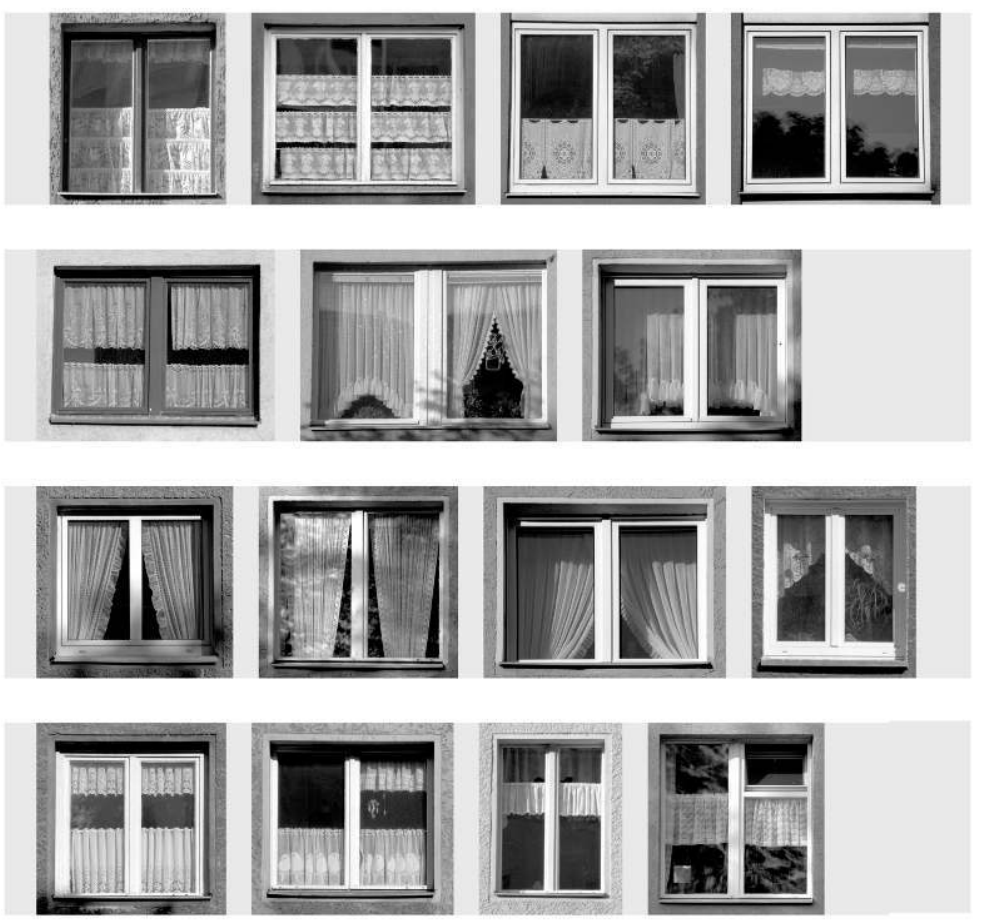

Photography and montage by Izai Amorim

\section{Background: The Twin Projects Berlin}

Working as an architect in Berlin in the early 1990s, I could experience the city's quick reconstruction first-hand. Fuelled by the desire to make Berlin a "normal" city again, the people in charge cleaned it up and made it nice and tidy, robbing it of its charms along the way: its past, its history, its scars, its ruins, and its beautiful decadence.

I didn't appreciate Berlin's new architecture very much. The fear of diversity, the irrational urge to control chaos, the aversion to experiments, the lack of vision, and last but not least the nostalgic flight back to an idealized past: all this has left its mark. With a few exceptions, one needs only two words to categorize these new, uninspiring, wellbehaved, boring, look-alike buildings: "rearranging rectangles." One day, looking back, people might regret the missed opportunities. 
40 Not much interested in the buildings that were being erected, I discovered something much better to look at: the lace curtains hanging behind the windows. I needed time to educate my eye. At first glance the curtains did not look beautiful. On contrary, they seemed ugly, tacky, sometimes even barbaric, the textile equivalent to sauerkraut with bratwurst. But with time I learned to differentiate between them, to delight on the "variations on the same theme." I rejoiced each time I discovered a new type. Slowly my feelings toward the curtains changed and someday I started to love them. To me, the lace curtains of Berlin are the proof that tackiness, when taken to extremes, can acquire a poetic dimension.

41 Interestingly, I didn't meet anyone else who shared my interest in the lace curtains. The most common comment I heard when talking about them was, "Which curtains?" Most people seemed oblivious to them even though you could find these curtains almost everywhere in Berlin. This made the subject even more interesting to me. Here you had an entire city "broadcasting" messages via lace curtains and nobody seemed to care - or even notice.

42 The best answer to the question "Which curtains?" would be a collection of photographs, showing in a concentrated way what a wonderful thing they are. Therefore I decided to photograph and catalogue them. But soon I realized that the photographs alone wouldn't be enough. I shouldn't expect people to see the lace curtains as messages, as I did. I needed to give them a concrete example of how someone could decipher them. At the time I was developing the plot for a book, set in Berlin, called "The Games." I decided to have one character in this novel "discover" the lace curtains and "decipher their meaning."

43 So the "Twin Projects Berlin" was born. "The Lace Curtains of Berlin as its graphic, nonfiction part - the neutral documentation; the novel "The Games" as its fiction part - the example for curtains as messages.

\section{The Graphic Part}


Wiener Street in Kreuzberg

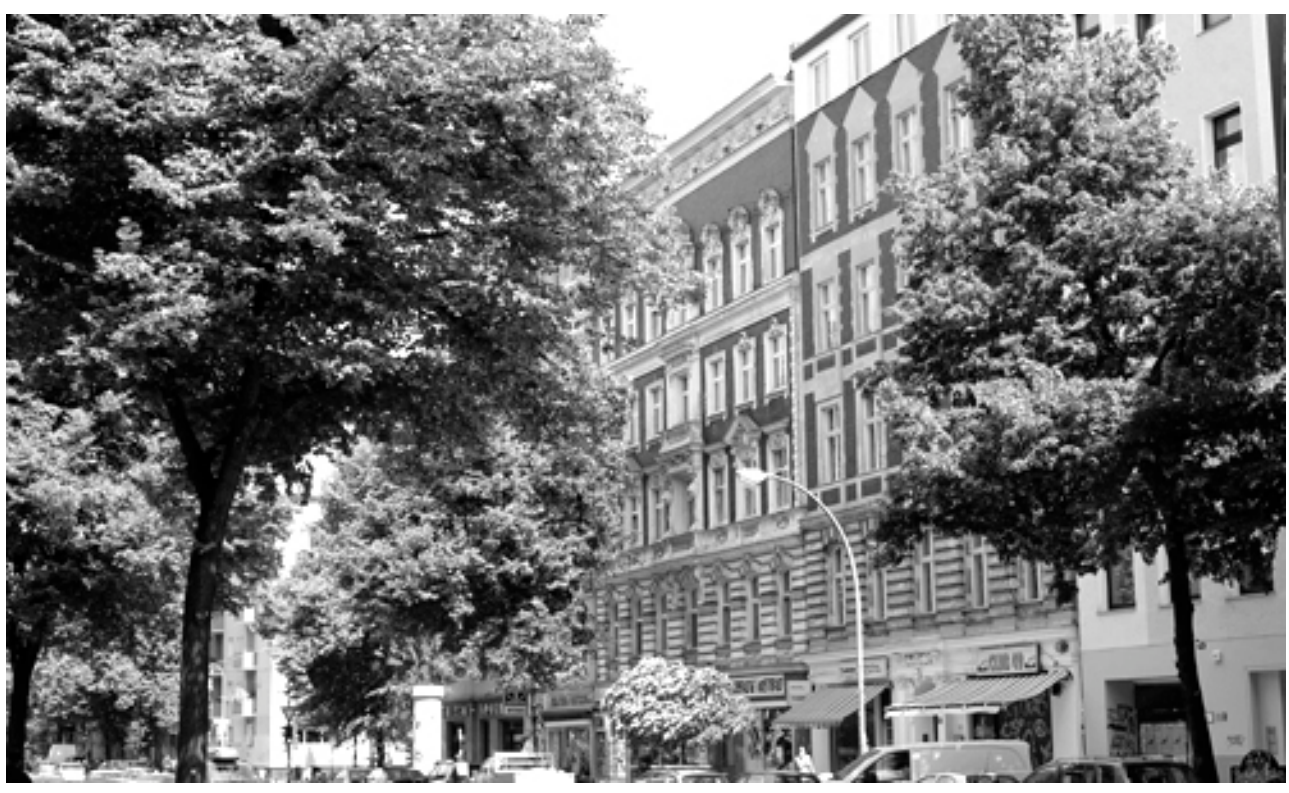

Photography by Izai Amorim

Ratibor Street in Kreuzberg

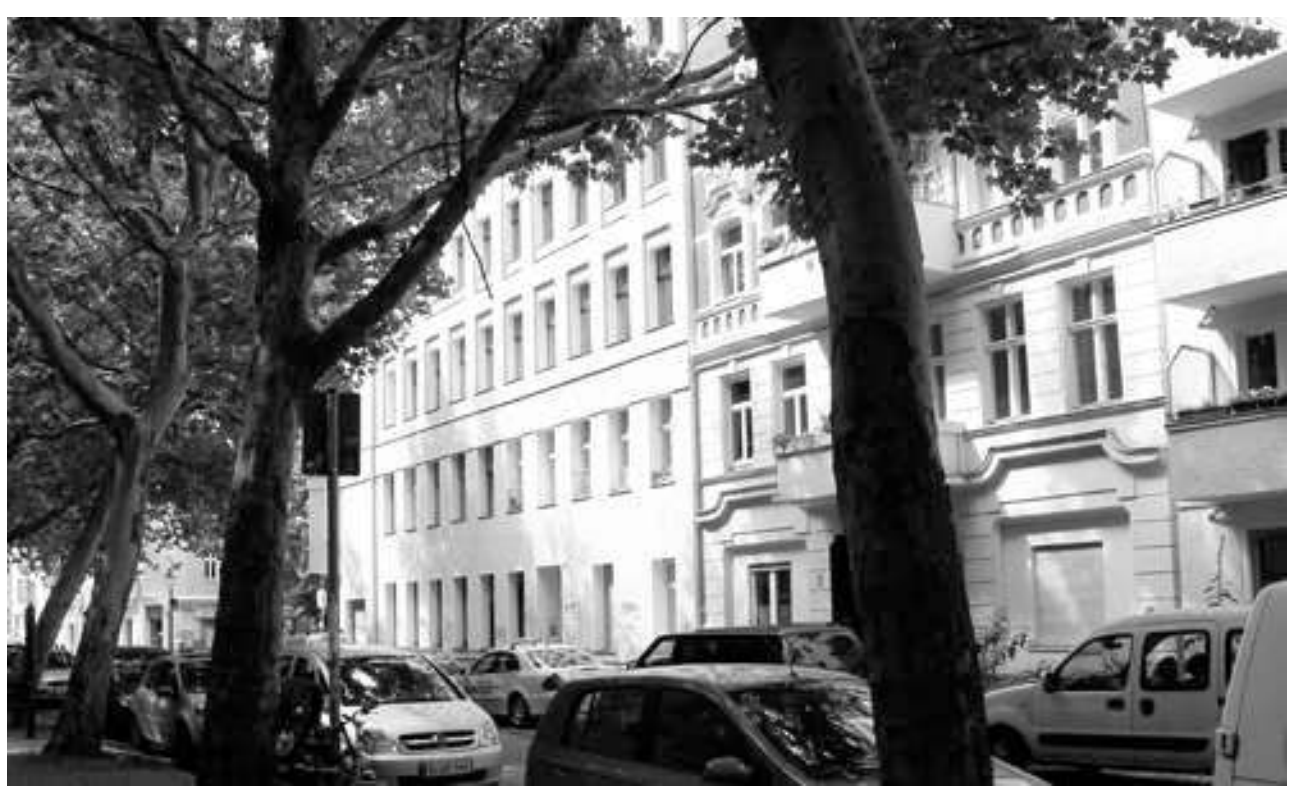

Photography by Izai Amorim

44 I chose to photograph the curtains in the neighborhoods of Kreuzberg and Neuköln. It took me a whole summer to finish the project. I had to shoot on the weekends and I needed good weather.

You can photograph the lace curtains for only two to three hours in the early morning. Because once the sun gets to a certain height, the windows reflect light like mirrors. So I had to hit the road very early, at about 6 a.m., and keep walking, searching, and shooting. For this reason, I don't know where and when each photograph was shot: there was no time for recordkeeping. 

The challenge was choosing which curtains to show and in which order. After innumerable trials I decided to group them according to window type: form, number of divisions, etc.

47 I identified eight different "families" or "collections" of windows. I named them after streets in the Görlitzer Park area of the Kreuzberg neighborhood, an area I am very fond of. This doesn't mean that all the lace curtains in a given collection were photographed in the street the collection is named after. I can't say where each picture was shot.

The project has its own website. The pictures were also published in a book in 2013.

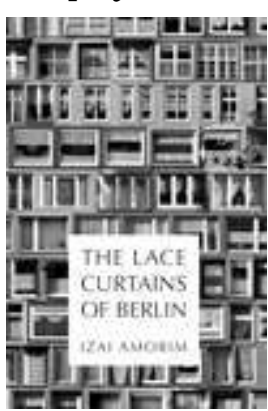

http://www.lacecurtains.izaiamorim.com

\section{The Fiction Part}

Building with Lace Curtains (1)

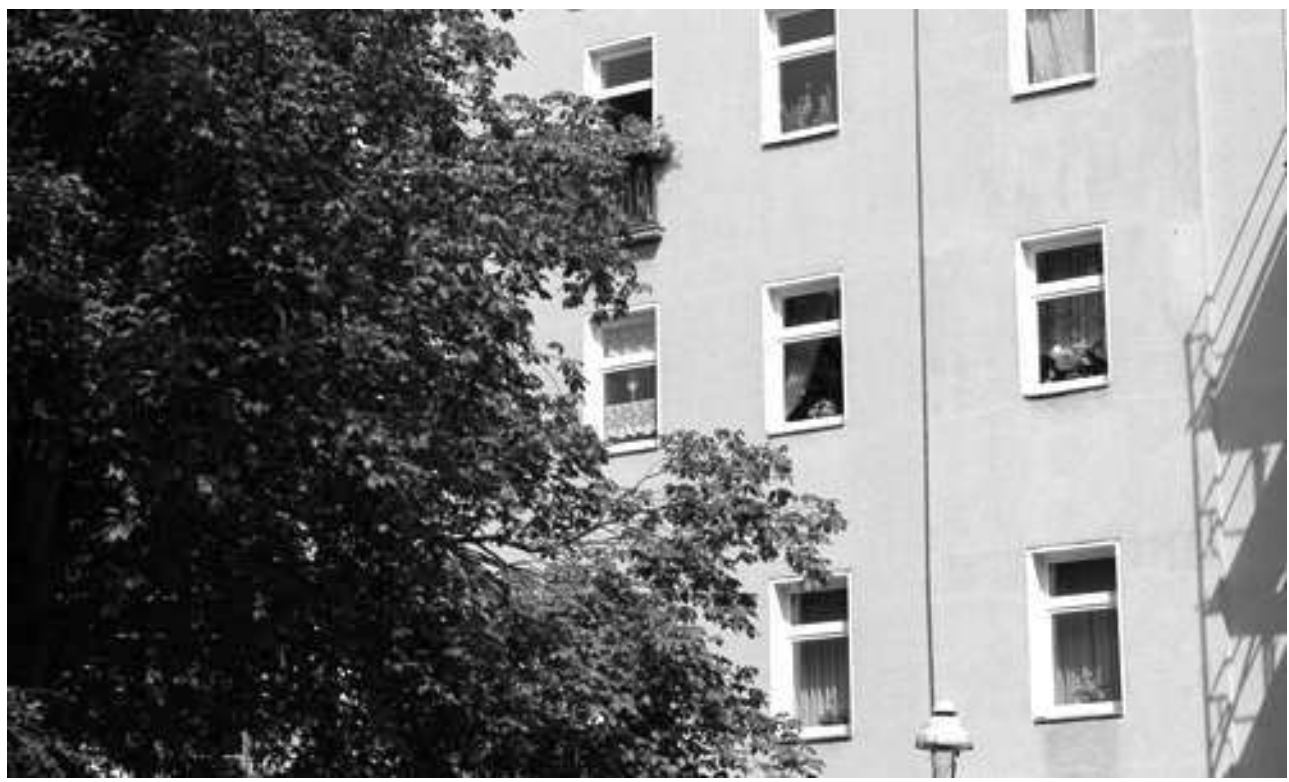

Photography by Izai Amorim 


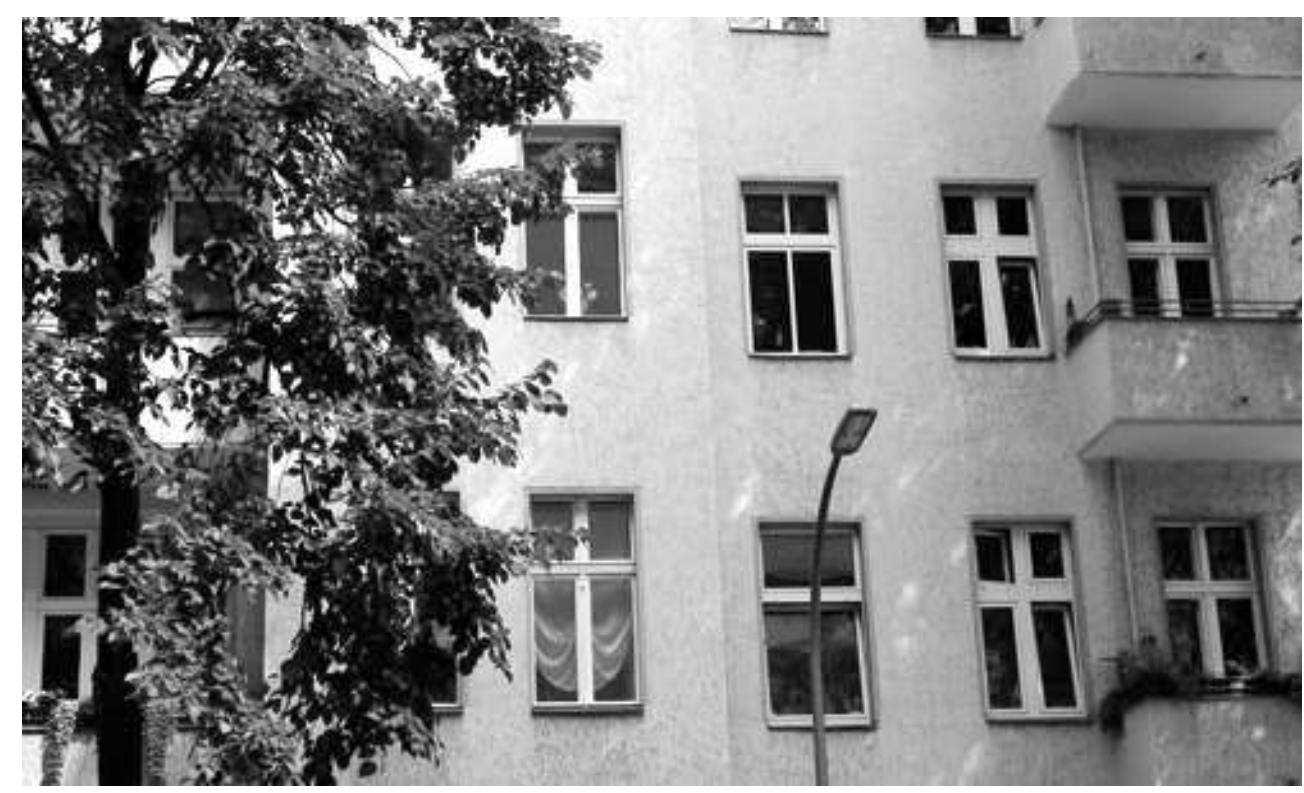

Photography by Izai Amorim

Photographing the curtains was also research for the character in my novel. "The Games" is a political novel about information, communication, storytelling, and power. I needed one of the characters to be a completely "analogue" person living in our "digital" world. Science-fiction writers would use a time machine. My best option was someone who had gone to prison in the mid-eighties and came out twenty-five years later, completely missing the digital revolution that took place in this period.

The character, Rainer-Werner Sprengberg, jailed for being a member of the fictive "Red Revolutionary Army," spent practically his whole life in Berlin but he only consciously notices the lace curtains for the first time the day when he leaves the penitentiary in 2010, aged sixty-two. Trying to find something that hasn't changed since he went to prison, that looks the same as before, he notices that the lace curtains have been there forever, unchanged, as if frozen in time.

"Who hangs these curtains?" he asks himself. "Conservative, conformist, narrow-minded people," he answers, attributing meaning to the curtains according to his bias. Exactly the same people who supported the so-called system he had tried to destroy, he concludes. Why had he been so foolish to expect their support for his armed struggle when the lace curtains were telling him loudly it was impossible? Why did he ignore the curtains' message?

53 The realization that he has wasted his life leads to a nervous breakdown. Afterwards Rainer-Werner decides to photograph the curtains. In his opinion, a lace curtain is very similar to him: both are real and material, not virtual; both have been around for decades; both are oblivious to everyone; what both "have to say" doesn't interest anyone. These similarities bring them together. He considers himself to be a scientist, a mixture of anthropologist and archaeologist, doing research on the curtains and their meaning. This way the lace curtains are woven into the story, making people aware of their existence and their potential as communication tools.

54 The novel was published in 2013. It also has a website. 


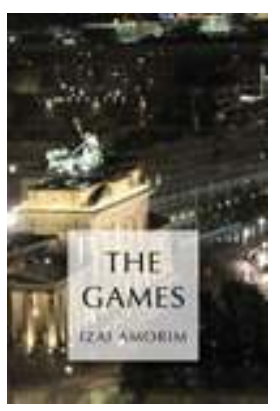

http://www.thegames.izaiamorim.com

\section{BIBLIOGRAPHY}

\section{Books}

Amorim Izai. 2013. The Lace Curtains of Berlin. North Charleston (SC): CreateSpace Independent Publishing Platform

Amorim Izai. 2013. The Games. North Charleston (SC): CreateSpace Independent Publishing Platform

Websites

http://www.izaiamorim.com

http://www.lacecurtains.izaiamorim.com

http://www.thegames.izaiamorim.com

\section{ABSTRACTS}

The project "The Lace Curtains of Berlin" is based on the author's assumption that the said lace curtains are very efficient communication tools. The curtains' main function seems to be ornamental since they don't block much light and don't guarantee much privacy. In general, ornaments can be Channels, Signals, or Messages. After rejecting lace curtains as Channels, the essay examines the remaining possibilities of lace curtains as Messages or Signals. The author leans towards the theory of curtains as Messages and hopes to inspire someone to study these messages seriously.

Le projet « les rideaux en dentelle à Berlin » est conçu à partir de l'hypothèse de l'auteur que ces rideaux sont des moyens de communication très efficaces. La fonction principale des rideaux semble être décorative puisqu'ils ne bloquent pas complétement la lumière et ne garantissent guère l'intimité. En général les décors peuvent être des Voies, des Signaux ou des Messages. Après avoir réfuté l'utilisation des rideaux comme des voies de communication, cet essai examine les autres fonctions des rideaux de dentelle comme Messages ou comme Signaux. L'auteur s'oriente vers la théorie des rideaux comme Messages and espère ainsi encourager quelqu'un à étudier ces messages sérieusement. 
El proyecto "The lace Curtains of Berlin" (las cortinas de encaje de Berlín) se basa en la idea de que las cortinas de encaje son herramientas de comunicación muy eficientes.La función principal de las mismas parece ser ornamental, pues ni bloquean mucha luz ni garantizan demasiada privacidad. En general, los ornamentos pueden ser Canales, Señales o Mensajes. Luego de rechazar las cortinas de encaje en tanto que Canales, el ensayo examina las otras dos posibilidades: las cortinas de encaje como Mensajes y como Señales. El autor se inclina por la teoría de la cortinas como Mensajes, con el deseo de inspirar otros autores a estudiar estos mensajes de forma seria.

\section{INDEX}

Keywords: ornaments, communication, message, meaning

Mots-clés: décors, signification

Palabras claves: Ornamento, Comunicación, Mensaje, Significado

\section{AUTHOR}

\section{IZAI AMORIM}

contact@izai-amorim.com

Izai Amorim was born and raised in Brazil but spent most of his adult life abroad, briefly in the USA, mostly in Germany. He was trained as an architect and worked many years in the profession. But his real passion is storytelling. At some point in his life he decided to mix storytelling with architecture, changed profession, and became a branding consultant, something that he loves and has been doing to these days. He has great interest in the interplay of media, information, and politics in a globalized world and the quest for meaning, identity, and borders in our worldwide cultural melting pot. 